\title{
Fat Measurement
}

National Cancer Institute

\section{Source}

National Cancer Institute. Fat Measurement. NCI Thesaurus. Code C96648.

The determination of the amount of fat present in a sample. 